\title{
AUDIT SISTEM INFORMASI MANAJEMEN DAN AKADEMIK (SIMAK) STT INDONESIA TANJUNGPINANG MENGGUNAKAN STANDAR COBIT 5.0 DOMAIN DSS (DELIVER, SERVICE, AND SUPPORT)
}

${ }^{1}$ Muhammad Firdiyansyah, ${ }^{2}$ Lois Frederik

Sekolah Tinggi Teknologi Indonesia, Jurusan Sistem Informasi

e-mail : 'mhdfirdiansyah@gmail.com, ${ }^{2}$ louisfrederick68@gmail.com

\section{ABSTRAK}

Sekolah Tinggi Teknologi Indonesia (STTI) Tanjungpinang adalah salah satu perguruan tinggi berbasis teknologi di Tanjungpinang. Berdiri pada tahun 2007, STTI Tanjungpinang telah banyak melakukan inovasi-inovasi untuk menunjang jalannya proses kegiatan belajar mengajar dan civitas akademika. Salah satu inovasi yang dilakukan adalah telah digunakannya Sistem Informasi Manajemen Akademik dan Keuangan (SIMAK). SIMAK adalah sistem yang digunakan di STTI Tanjungpinang dengan penanggung jawab pengelolaan nya diserahkan kepada pusat pengolahan data (PUSLAHTA). Data-data yang masuk antara lain data-data mahasiswa,data nilai mahasiswa,data krs mahasiswa,dan data lainnya. PUSLAHTA di STTI Tanjungpinang dikelola oleh satu orang kepala bagian PUSLAHTA dan dibantu oleh staf. Dikarenakan begitu banyak dilakukannya pengolahan data di SIMAK,menjadikan SIMAK merupakan salah satu sistem yang paling sering digunakan oleh mahasiswa dan dosen ataupun civitas akademika yang lain.

SIMAK yang digunakan selama ini belum pernah dilakukan audit secara menyeluruh,oleh karena itu perlu adanya audit agar dilakukan evaluasi terhadap kekurangan-kekurangan pada SIMAK dan mempertahankan atau merubah agar bisa menjadi lebih baik. Audit yang dilakukan adalah menggunakan standar COBIT versi 5.0 dengan mengambil domain Deliver, Service, and Support (DSS). Domain ini diambil dikarenakan perlu mengetahui seperti apa pengawasan yang telah dilakukan,kemudian mengevaluasi atas apa yang menjadi kekurangan dan memberikan penilaian terhadap apa yang selama ini telah dilakukan.

Kata kunci : STTI Tanjungpinang, SIMAK, Audit, Cobit 5.0, domain DSS.

\section{PENDAHULUAN}

Sekolah Tinggi Teknologi Indonesia Tanjungpinang (STT Indonesia Tanjungpinang) sebagai salah satu perguruan tinggi berbasis teknologi di Tanjungpinang telah memiiki beberapa sistem yang dapat membantu pekerjaan dan aktifitas karyawan dan dosen. Sistem-sistem yang dimiliki antara lain Sistem 
Informasi Manajemen Akademik dan Kemahasiswaan (SIMAK), Sistem Informasi Ujian Akhir Semester(SIUAS), Sistem Informasi Perpustakaan (E-Library), dan Sistem Informasi Kepegawaian (SIMPEG).

SIMAK STT Indonesia Tanjungpinang merupakan salah satu sistem yang dimiliki oleh STT Indonesia Tanjungpinang. Selama SIMAK ini digunakan belum pernah dilakukan audit secara menyeluruh, oleh karena itu perlu adanya audit atau peninjauan yang dilakukan agar dapat dilakukan evaluasi terhadap kekurangankekurangan pada SIMAK, serta mempertahankan atau meningkatkan mutu dan kualitas SIMAK. Audit yang dilakukan menggunakan standar COBIT versi terbaru yaitu COBIT versi 5.0. Di dalam COBIT versi 5.0 terdapat 37 referensi proses di dalam tata kelola teknologi informasi. 37 proses referensi tersebut terbagi dalam 4 domain antara lain Align, Plan, and Organize (APO) yang memiliki 13 sub domain, Build, Acquare, and Implement (BAI) yang memiliki 10 sub domain, Deliver, Service and Support (DSS) yang memiliki 6 sub domain, dan Monitor Evaluate Assess (MEA) yang memiliki 3 sub domain. Di dalam penelitian ini penulis mengambil domain Deliver, Service and Support (DSS).

Dalam penelitian ini penulis mengambil responden untuk pengisian kuesioner penelitian yaitu user dari SIMAK yaitu Mahasiswa, Dosen, Dosen Wali, dan Manajemen. Pihak-pihak yang dilakukan wawancara untuk pengumpulan data penelitian adalah Bapak Sugeng Riyantho, ST (operator hardware), Bapak Mochammad Rizki Romdhoni S.Kom., MT (penanggung jawab software) dan Bapak Danandjaya Saputra, ST (staf puslahta). Dengan adanya audit terhadap SIMAK ini diharapkan didapatkan hasil penelitian mengenai capability level dan rating scale untuk dapat memberikan penilaian atau evaluasi terhadap kelebihan dan kekurangan SIMAK. Kelebihan untuk dapat dipertahankan dan kekurangan untuk dapat diperbaiki agar SIMAK ke depannya dapat berkembang sesuai dengan kebutuhan.

\section{KAJIAN PUSTAKA \\ 2.1 Audit}

Kata 'audit 'berasal dari Bahasa Latin 'Audire' (Picket,2005,p.4) yang berarti 'mendengar' (the word Audit berasal dari bahasa Latin audire) yang berarti to hear, yaitu pada zaman dahulu apabila seorang pemilik organisasi usaha merasa ada suatu kesalahan atau penyalahgunaan, maka ia mendengarkan kesaksian orang tertentu. Pada zaman itu apabila pemilik suatu badan usaha mencurigai adanya kecurangan, mereka akan menunjuk orang tertentu untuk memeriksa perusahaan. Orang yang memiliki kompetensi untuk melakukan audit disebut auditor.

\subsection{SIMAK}

SIMAK yang merupakan kepanjangan dari Sistem Informasi Manajemen Akademik dan Keuangan adalah salah satu sistem yang telah dimiliki STT Indonesia Tanjungpinang. Sistem yang dibentuk dan mulai digunakan pada tahun 2009 ini dirancang dan di produksi langsung oleh salah satu dosen di STT Indonesia 
Tanjungpinang yaitu Bapak Moch.Rizki Romdoni, S.Kom., MT dan dibantu oleh beberapa dosen di lingkungan STT Indonesia Tanjungpinang.

Untuk saat ini baik mahasiswa ataupun civitas akademika STT Indonesia Tanjungpinang mengakses laman SIMAK melalui alamat url yaitu http://180.242.93.57/ simakreal/index.php?page=Users.Login.

SIMAK yang dirancang dan diciptakan di STT Indonesia Tanjungpinang ini menggunakan jenis bahasa pemrograman PHP dan menggunakan database My SQL. Server SIMAK ini terdapat di Ruang Pusat Komunikasi (PUSKOM) lantai 3. Dengan selalu dilakukannya update data minimal 7 hari sekali,maka seluruh database SIMAK dapat dikelola dan terlindungi dari ancaman yang serius. Untuk saat ini wewenang penuh dan pengelolaan SIMAK dikelola oleh bagian Pusat Pengolahan Data (Puslahta) yang beranggotakan seorang Kepala Puslahta dan dibantu oleh satu orang staf Puslahta.

Kegunaan SIMAK antara lain sebagai berikut :

1. Menginputkan data pribadi mahasiswa.

2. Menginputkan nilai mahasiswa.

3. KRS online mahasiswa.

4. Data keuangan.

5. Cetak Kartu Studi Mahasiswa.

6. Cetak transkrip nilai Mahasiswa

\subsection{COBIT}

COBIT (Control Objective for Information and related Technology) adalah suatu standarisasi di dalam melakukan praktek di lapangan untuk mengelola manajemen teknologi informasi. Standar COBIT dilakukan oleh Information Technology Governance ( IT Governance) yang merupakan bagian dari ISACA (Information Systems Audit and Control Association) atau Asosiasi Audit dan Pengawasan Sistem Informasi. ISACA adalah suatu organisasi yang beranggotakan para auditor sistem informasi, konsultan, pengajar, professional keamanan sistem informasi yang saat ini telah memiliki kurang lebih 95.000 anggota di 160 negara, termasuk Indonesia. Saat ini COBIT telah mengalami beberapa regenerasi yaitu COBIT 1 yang muncul pada tahun 1996, COBIT 2 yang muncul pada tahun 1998, COBIT 3 yang muncul pada tahun 2000, COBIT 4 - COBIT 4.1 yang muncul pada tahun 2005-2007 dan versi terakhir COBIT 5 yang muncul pada tahun 2012.

\subsubsection{Kriteria Informasi COBIT}

Untuk memenuhi tujuan bisnis, informasi yang dibutuhkan dan menjadi perhatian COBIT harus memenuhi kriteria, antara lain :

1. Efektivitas, yaitu informasi yang diperoleh harus relevan dan berkaitan dengan proses bisnis,konsisten dapat dipercaya,dan tepat waktu.

2. Efisiensi, yaitu penyediaan informasi melalui penggunaan sumber daya yang optimal. 
3. Kerahasiaan, yaitu berkaitan dengan proteksi pada informasi penting dari pihak-pihak yang tidak memiliki hak otorisasi atau tidak wewenang.

4. Integritas, yaitu informasi yang berkaitan dengan keakuratan dan kelengkapan data atau informasi dan tingkat validitas yang sesuai dengan ekspektasi dan nilai bisnis.

5. Ketersediaan, yaitu informasi harus fokus terhadap ketersediaan data ketika diperlukan dalam proses bisnis, baik saat ini ataupun yang akan datang.

6. Compliance, yaitu pemenuhan data atau informasi yang sesuai dengan ketentuan hukum,peraturan,dan rencana perjanjian atau kontrak untuk proses bisnis.

7. Reliability, yaitu informasi haruslah fokus pada pemberian informasi yang tepat bagi manajemen untuk mengoperasikan perusahaan dan pemenuhan kewajiban mereka untuk membuat laporan keuangan.

\subsubsection{Kegunaan COBIT}

COBIT merupakan suatu metodologi yang terdiri dari standar dan pengendalian yang difungsikan untuk membantu organisasi dalam menerapkan, mereview, dan memantau lingkungan teknologi informasi. COBIT yang dirumuskan oleh ISACA memiliki misi untuk melakukan pengembangan, melakukan riset dan mempublikasikan suatu standar teknologi informasi yang dapat diterima secara umum.

Tujuan utama COBIT adalah memberikan kebijaksanaan yang jelas bagi IT Governance, bagi organisasi di seluruh dunia untuk membantu manajemen agar memahami, mengatur, dan memperkecil resiko-resiko yang berhubungan dengan teknologi informasi. COBIT melakukannya dengan menyediakan kerangka kerja IT Governance dan petunjuk kontrol obyektif yang detail bagi manajemen, pemilik proses bisnis, serta user atau auditor.

Kegunaan COBIT yang lain ialah sekumpulan dokumentasi best practices yang dapat membantu auditor, pengguna (user), dan manajemen untuk memfasilitasi gap antara resiko bisnis, kebutuhan kontrol dan masalah-masalah teknis teknologi informasi.

\subsection{COBIT 5.0}

COBIT 5 adalah kerangka bisnis untuk pengelolaan dan manajemen dari pada teknologi informasi suatu perusahaan. COBIT 5 adalah edisi terbaru dari framework COBIT ISACA yang menyediakan penjabaran bisnis secara end to end dari tata kelola teknologi informasi perusahaan untuk menggambarkan peran utama dari informasi dan teknologi dalam menciptakan nilai perusahaan. COBIT 5 dibangun dan diperluas dari COBIT 4.1 yang mana merupakan versi sebelumnya dari COBIT 5.0. 


\subsubsection{Kegunaan COBIT 5.0}

Kegunaan COBIT 5 antara lain :

1. Memelihara informasi yang berkualitas tinggi untuk membantu perusahaan di dalam keputusan bisnis.

2. Tercapainya tujuan strategis melalui penggunaan teknologi informasi yang kreatif dan inovatif.

3. Tercapainya tingkat operasional perusahaan yang unggul melalui kehandalan dan efisiensi penerapan teknologi.

4. Menjaga terkait resiko teknologi informasi perusahaan pada tingkat yang dapat diterima oleh pimpinan perusahaan.

5. Mengoptimalkan biaya dari layanan terhadap teknologi informasi perusahaan.

6. Mendukung kepatuhan terhadap hukum yang berlaku, regulasi, perjanjian kontrak dan kebijakan lainnya

\subsubsection{Prinsip COBIT 5.0}

COBIT 5 didasari oleh 5 prinsip kunci dalam menjalankan governance dan management suatu teknologi informasi di dalam perusahaan. 5 prinsip itu antara lain :

1. Meeting stakeholder needs

2. Covering the enterprise End-to-End

3. Applying a single, integrated framework

4. Enabling a holistic approach

5. Separating governance from manageme

\subsubsection{Model Kapabilitas dalam COBIT 5.0}

COBIT 5.0 memiliki enam tingkatan kapabilitas yang dapat dicapai antara lain :

1. Level 0 (Incomplete Process) adalah level dimana proses tidak diimplementasikan atau gagal untuk mencapai tujuan proses yang diinginkan. Pada level ini,ada sedikit atau tidak ada sama sekali bukti dari pencapaian yang sistematik.

2. Level 1 (Performed Process) adalah level dimana proses diimplementasikan untuk mencapai tujuan prosesnya.

3. Level 2 (Managed Process) adalah level dimana Proses yang dijelaskan sebelumnya kini diimplementasikan di dalam suatu pengelolaan (perencanaan,pengawasan,penyesuaian) dan produk pengerjaan secara tepat ditetapkan,diawasi dan dipelihara

4. Level 3 (Established Process) adalah level dimana Proses yang dikelola pada level 2,kini diimplementasikan menggunakan proses yang dijelaskan yang mampu mencapai hasil prosesnya

5. Level 4 (Predictable Process) adalah level dimana proses yang ditetapkan telah dijelaskan sebelumnya sekarang dioperasikan dengan menentukan batas untuk mencapai hasil prosesnya. 
6. Level 5 (Optimising Process) adalah level dimana proses yang diprediksikan kemudian dilanjutkan untuk memenuhi tujuan bisnis yang relevan dan tujuan yang akan datang.

\subsubsection{Skala Penilaian (Rating Scale)}

Skala penilaian pada COBIT 5.0 antara lain :

1. $\mathrm{N}$ (Not achieved) adalah situasi dimana Ada sedikit atau tidak ada bukti pencapaian atribut yang didefinisikan dalam penilaian proses. Skala pencapaian $0-15 \%$.

2. P (Partially achieved) adalah situasi dimana Ada beberapa bukti pendekatan, dan beberapa pencapaian, yang didefinisikan atribut dalam proses yang dinilai. Beberapa aspek pencapaian atribut mungkin tidak dapat diprediksi. Skala pencapaian $15-50 \%$.

3. L (Largely achieved) adalah situasi dimana Ada bukti adanya pendekatan sistematis dan pencapaian yang signifikan dari atribut yang didefinisikan dalam proses yang dinilai. Beberapa kelemahan yang terkait dengan atribut ini mungkin ada dalam penilaian proses. Skala pencapaian $50-85 \%$.

4. $\quad \mathrm{F}($ Fully achieved $)$ adalah situasi dimana Ada bukti pendekatan yang lengkap dan sistematis, dan pencapaian penuh dari atribut yang didefinisikan dalam proses yang dinilai. Tidak ada kelemahan signifikan yang berhubungan dengan atribut ini. Skala pencapaian $85-100 \%$.

\subsubsection{Domain dan Proses COBIT 5.0}

COBIT 5 memiliki 2 domain yang terbagi dalam dua proses yaitu proses governance dan management. Masing-masing proses memiliki subproses masing-masing. Proses governance atau proses tata kelola adalah proses persetujuan tata kelola perusahaan dengan pemangku kepentingan yang berkaitan dengan sasaran dan nilai yang ingin di capai, optimasi resiko dan sumber daya dan termasuk aktivitas-aktivitas yang bertujuan untuk mengevaluasi pilihan-pilihan yang strategis, memberikan arahan untuk IT Perusahaan dan pemantauan hasil atau target yang ingin dicapai. Domain yang termasuk dalam proses Governance adalah Evaluate, Direct, and Monitor (EDM) yang terdiri dari 5 proses. Sedangkan proses Management atau proses manajemen adalah sejalan dengan aktivitas-aktivitas di dalam manajemen perusahaan yang mencakup area Plan, Build, Run, and Monitor (PBRM). Keempat area tersebut memiliki 39 proses yang disebut dengan proses referensi model atau Process Reference Model (PRM). 39 proses tersebut terbagi menjadi 4 domain, yaitu sebagai berikut : 
1. Domain Align, Plan, and Organize (APO) atau domain menyelaraskan, merencanakan, dan mengatur

2. Domain Build ,Acquire, Implement (BAI) atau domain membangun, memperoleh dan menerapkan

3. Domain Deliver, Service, Support (DSS) atau domain memberikan, dukungan dan layanan.

4. Domain Monitor, Evaluate, dan Assess (MEA) atau domain memantau, mengevaluasi dan menilai.

\subsection{Profil STT Indonesia Tanjungpinang}

Sekolah Tinggi Teknologi Indonesia telah berdiri sejak tahun 1990 di kota Bandung yang merupakan perguruan tinggi yang berada di bawah naungan Yayasan Penelitian dan Pengembangan Komputer Indonesia.

Dalam operasional akademik, STT Indonesia ini telah membuka beberapa Program Studi antara lain Teknik Informatika jenjang S1, Sistem Informasi jenjang $\mathrm{S} 1$, yang untuk selanjutnya program studi tersebut masing-masing telah terakreditasi oleh Badan Akreditasi Nasional Perguruan Tinggi (BAN-PT).

Mulai Tahun Akademik 2007/2008 berdasarkan Surat Keputusan Menteri Pendidikan Nasional Republik Indonesia No.79/D/O/2007 tanggal 18 Juni 2007, STT Indonesia yang semula beroperasi di Kota Bandung dipindah ijinkan operasionalnya secara mandiri ke Kota Tanjungpinang, Provinsi Kepulauan Riau, sehingga tidak ada STT Indonesia yang beroperasi di Kota Bandung atau kota lainnya selain Kota Tanjungpinang. Saat ini STT Indonesia Tanjungpinang telah membuka beberapa program studi. Program studi tersebut telah terakreditasi oleh BAN-PT. Adapun program studi yang terkakreditasi tersebut antara lain :

1. Teknik Informatika

Jenjang program sarjana (S-1). Terakreditasi oleh BAN-PT sesuai keputusan BAN-PT No. 2780/SK/BAN-PT/Akred/S/XI/2016.

2. Sistem Informasi

Jenjang program sarjana (S-1). Terakreditasi oleh BAN-PT sesuai keputusan BAN-PT No. 1502/SK/BAN-PT/Akred/S/VIII/2016

3. Sistem Informasi konsentrasi Komputer Akuntansi Jenjang program sarjana (S-1). Terakreditasi oleh BAN-PT.

\subsubsection{Visi dan Misi}

Visi STT Indonesia Tanjungpinang yaitu " Menjadi pusat pendidikan berkualitas dalam bidang teknologi khususnya teknologi informasi berskala nasional." berikut:

Sedangkan Misi STT Indonesia Tanjungpinang antara lain sebagai

1. Menyelenggarakan pendidikan dan pelatihan teknologi khususnya teknologi informasi terapan dengan menjalin kemitraan dengan pemerintah, lembaga swadaya dan industri. 
2. Menyelenggarakan penelitian dalam bidang teknologi informasi terapan untuk membantu lembaga dan dunia industri dalam meningkatkan kinerjanya

3. Melaksanakan program pemberdayaan masyarakat dalam pemanfaatan teknologi informasi yang tepat guna dan berdaya guna di sumatera dan sekitarnya.

4. Membangun hubungan kerja yang harmonis dengan penuh rasa kekeluargaan dan etos kerja yang baik untuk meraih prestasi yang lebih baik.

\section{METODOLOGI PENELITIAN}

Merupakan suatu teknik atau cara untuk mengumpulkan data atau fakta yang nantinya akan dipelajari dan digunakan sebagai bahan untuk memudahkan pencarian pemecahan suatu masalah.

\subsection{Metode Pengumpulan Data}

Metode yang digunakan untuk mendapatkan data yang diperlukan sebagai berikut :

1. Observasi

Observasi merupakan teknik atau pendekatan untuk memahami dan mendapatkan data primer dengan cara mengamati langsung obyek yang diamati. Dalam hal penelitian ini, tentunya hal yang diamati adalah Sistem Informasi Manajemen Akademik dan Keuangan STT Indonesia Tanjungpinang.

2. Wawancara

Wawancara adalah cara menjaring informasi atau data melalui interaksi verbal atau lisan kepada orang-orang yang terlibat di dalam komponen penelitian. Wawancara dapat berupa wawancara personal,wawancara intersep,dan wawancara telepon. Wawancara personal ialah wawancara langsung dengan narasumber. Wawancara intersep adalah wawancara yang proses nya sama dengan wawancara personal,akan tetapi narasumber dipilih secara acak di lokasi-lokasi umum atau keramaian. Dalam hal penelitian ini,tentunya penulis mengambil wawancara personal,yaitu melakukan wawancara kepada pihak-pihak yang terlibat di dalam SIMAK.

\section{Kuesioner}

Kuesioner merupakan salah satu teknik pengumpulan data yang dilakukan oleh penulis. Kuesioner digunakan untuk mengetahui keadaaan fakta yang terjadi terhadap penggunaan SIMAK itu sendiri. Dalam hal ini,kuesioner akan disebarkan kepada pengguna SIMAK yaitu dikalangan Dosen,Mahasiswa,serta Civitas Akademika Kampus.

Pada penelitian ini digunakan kuesioner dengan menggunakan Skala Likert. Skala Likert digunakan mengukur respon subjek dalam 5 atau 7 poin skala dengan interval yang sama. 


\subsection{Jenis Penelitian}

Penelitian ini menggunakan jenis penelitian deskriptif kuantitatif. Penelitian deskriptif adalah penelitian yang dilakukan untuk mendeskripsikan menjelaskan terhadap fenomena-fenomena yang dihadapi sekarang berdasarkan data-data yang valid. Tujuan dari penelitian deskriptif ini adalah untuk menggambarkan secara sistematis fakta dan karakteristik objek atau suatu yang diteliti secara tepat.

\subsection{Sumber Data}

Dalam penelitian dikenal dua jenis data,yaitu Data Primer dan Data Sekunder. Data Primer adalah data yang diperoleh dari penulis atau peneliti langsung. Data ini didapat dari proses melakukan wawancara,studi lapangan,ataupun pembagian kuesioner. Sedangkan Data Sekunder adalah data yang didapat bersumber dari orang atau kelompok tertentu,misalnya data didapat dari Lembaga Surveri,BPS,dan lain sebagainya.

\subsection{Metode Pengujian dan Analisis Data}

Analisis data merupakan proses yang dilakukan setelah proses pengumpulan data. Ketika peneliti sudah selesai dalam mengumpulkan data,maka langkah berikutnya adalah menganalisis data yang diperoleh.

\subsubsection{Metode Deskriptif}

Metode deskriptif adalah metode pencarian fakta dengan interpretasi yang tepat. Metode desktriptif merupakan metode penelitian yang berusaha mengungkap fakta suatu kejadian, objek, aktivitas, proses dan manusia secara fakta dan menyeluruh. Tujuan dari penelitian deskriptif ini antara lain adalah untuk survei yang bersifat normative, bertujuan untuk mengadakan klasifikasi dan penelitian terhadap fenomena-fenomena dengan menetapkan suatu standar atau norma tertentu, serta melukiskan atau menggambarkan variabel tertentu sesuai dengan kondisi sebenarnya

\subsection{Pemilihan Populasi dan Sampel \\ 3.6.1 Populasi}

Populasi adalah sumber data dalam penelitian tertentu yang memiliki jumlah obyek atau jumlah subjek tertentu yang ditetapkan oleh peneliti. Jika data diambil dari keseluruhan objek yang ada di suatu populasi, tentunya akan memerlukan dana dan waktu yang cukup banyak. Oleh karena itu, perlu adanya pemilihan responden atau sumber data yang tidak begitu banyak. Dalam penelitian ini,populasi nya adalah seluruh pengguna SIMAK.

\subsubsection{Sampel}

Secara umum, terdapat dua jenis teknik pengambilan sampel yaitu, sampel acak atau random sampling dan sampel tidak acak atau non random sampling. Random sampling adalah cara pengambilan sampel yang memberikan kesempatan yang sama untuk diambil pada setiap elemen populasi. Sedangkan Non Random Sampling adalah setiap elemen populasi tidak mempunyai kemungkinan yang sama untuk dijadikan sampel. teknik 
pengambilan sampel yang digunakan oleh penulis adalah Judgement Sampling. Judgement Sampling adalah Purposive Sampling dengan kriteria pertimbangan tertentu. Kriteria tersebut yaitu Memiliki user pada SIMAK dan masih menggunakan SIMAK pada saat penelitian dilakukan

\section{HASIL DAN PEMBAHASAN}

\subsection{Objek Penelitian}

Objek penelitian yang diteliti oleh yaitu SIMAK STT Indonesia Tanjungpinang. Adapun user dari sistem ini adalah dari kalangan mahasiswa, dosen, serta civitas akademika STT Indonesia Tanjungpinang.

\subsection{Proses Domain DSS pada COBIT 5.0}

Secara keseluruhan, domain DSS pada COBIT 5.0 ini terbagi menjadi 6 (enam) proses, antara lain :

1. DSS 01- Mengelola Operasi (Manage Operation)

2. DSS 02- Mengelola Layanan Permintaan dan Kasus (Manage Service Request and Insident)

3. DSS 03- Mengelola Permasalahan (Manage Problem)

4. DSS 04- Mengelola Kelancaran (Manage Continuity)

5. DSS 05- Mengelola Layanan Keamanan (Manage Secutiry Service)

6. DSS 06- Mengelola Kontrol Proses Bisnis (Manage Process Business Control)

Dari keenam proses diatas, dibagi lagi menjadi beberapa proses.

\subsection{Hasil Pengolahan Data}

\subsubsection{Hasil Wawancara}

Berdasarkan wawancara yang telah dilakukan penulis kepada pihakpihak yang terlibat di dalam pengelolaan SIMAK, maka dapat ditemukan hasil dari wawancara antara lain :

1. Peralatan-peralatan hardware selalu dirawat, dicek,dan diawasi setiap hari serta di perbaiki jika terjadi permasalahan.

2. SIMAK STT Indonesia Tanjungpinang menggunakan operation system yaitu Linux, sehingga aman dari virus.

3. Kegiatan maintenance peralatan-peralatan hardware pendukung SIMAK dilakukan dengan cara selalu mengecek kabel, server, modem dan jaringan apakah dalam keadaan normal atau tidak.

4. Back up data dilakukan seminggu sekali dan secara rutin dilakukan.

5. Terdapat perbedaan hak akses antara mahasiswa, dosen, dosen wali, dan manajemen.

6. Hak akses itu seperti misalkan mahasiswa dapat mengisi KRS online, melihat Nilai, mencetak transkrip nilai dan KHS. Jika 
ERROR: syntaxerror

OFFENDING COMMAND: --nostringval--

STACK : 